\title{
HARD WATER REGIMES DURING PRE-MONSOONAL PERIOD IN RAJNAGAR BLOCK, ODISHA, INDIA: A GEOSPATIAL ANALYSIS BY GEOGRAPHIC INFORMATION SYSTEM
}

\author{
Prabhu Prasad Das ${ }^{1}$, H. K. Sahoo ${ }^{2}$ \\ ${ }^{I}$ Department of Geology, Utkal University, Bhubaneswar, Odisha, India \\ ${ }^{2}$ Department of Geology, Utkal University, Bhubaneswar, Odisha, India
}

\begin{abstract}
From the hydrochemical analysis of 53 representative groundwater samples along coastal Kendrapara district, Odisha, the current research establishes widespread occurrences of moderately hard to hard groundwater within the subsurface water bearing horizons. There exists a distinct belt of moderately hard ground water in the Rajnagar block of the district whereas soft water occurrence is practically absent in the study area. The analysis also points to no specific interrelationship between the hardness of groundwater to that of the physical parameters including $\mathrm{pH}$ and electrical conductance.
\end{abstract}

Keywords: Aquifer, Total Hardness, SRTM, GIS

\section{INTRODUCTION}

Hardness is the characteristic of water which inhibits the leathering of soap [1]. Groundwater hardness is primarily the function of divalent cations including calcium, magnesium, strontium, ferrous iron and manganous manganese [2]. However, looking at the predominance of the ions, hardness in groundwater is cardinally contributed to the presence of calcium and magnesium cation. These ions of hard ground waters form precipitates by reaction with soap as they do also form scales by reaction with certain anions present in the water [4]. Hence, hard ground waters contribute to the greater soap consumption as well as scaling of boilers and tastelessness of foods [2].

The cardinal source of the calcium and magnesium ions in groundwater is dissolution of limestone [2]. Dissolved carbon dioxide in rain water and that entering the infiltrating water into the subsurface horizons from microbial action within the soil zone and that of the root zone of vegetation leads to higher concentration of carbonic acid which in turn further lowers the $\mathrm{pH}$ conditions. This enhances the solution of insoluble carbonates in the soil zone which in limestone terrain leads to the conversion of more soluble bicarbonates as well as higher concentration of sulphates, chlorides and silicates as they pass into the subsurface water as exposed impurities once the carbonates are dissolved [2, 3, 4]. This is the reason why, hard ground waters normally originate in terrains where thick toposoils overlie limestone strata [3].

Hardness of groundwater caused due to the presence of carbonate and bicarbonate of calcium and magnesium are termed as temporary or carbonate hardness as they can be removed to some extent by simple boiling and addition of lime [4]. However, hardness caused due to the sulphates, chlorides and nitrates of calcium and magnesium are often referred to as permanent hardness as they require special softening treatment for removal of hardness [4]. This chemical property of the subsurface waters is expressed in $\mathrm{mg} / \mathrm{litre}$ or $\mathrm{ppm}$. equivalent of calcium carbonates which denotes to the calcium carbonate equivalent of calcium and magnesium ions present in water [1].

Hardness of groundwater is often directly correlated with the biological productivity as calcium and magnesium, the cardinal hardness cation contribute to productivity [2]. However, other hardness ions have a very adverse toxic effect on productivity if present in significant concentrations [2]. Although hardness and alkalinity have a positive corelationship and in many terrains often replicate each other, it is historically easier to measure the former one [2]. However, the use of hardness as a measure of productivity has become obsolete and other indices of productivity are followed for aquatic ecosystems. But, hard water are normally referred to as soap wasting waters and are the primary cause of scum in domestic usages [2].

The present research looks into the occurrences of hard water along the eastern coast of Odisha including the Rajnagar block of coastal Kendrapara district. The study takes into account the measured total hardness from 53 representative groundwater samples for the spatial variation of hard waters in the aforementioned block of the state [5, $6]$.

\section{STUDY AREA}

The present research deals with the aquifer systems of Rajnagar block of Odisha along the east coast of India (Fig. 1). The block encompasses an area of approximately $650 \mathrm{sqkm}$ with an estimated circumference of about $185 \mathrm{~km}$. It is situated on the east coast of Odisha along the Bay of Bengal. The river Brahmani flows through this region before 
merging into the sea. No wonder, the region is made up of the fluvio-deltaic deposits of this river and its tributaries. As the region lies along the sea, it does contain marine erosional as well as depositional features. The block forms the northern/northeastern boundary of the Kendrapara district and is bounded by Bhadrak district on the north. The Patamundai and Mahakalapara blocks constitute the northwestern and southwestern boundaries of the study area. Having a very close proximity to the area of interest along the coastline towards southeast, situated is the Paradeep port, one of the major industrial hubs of Odisha. In stark contrast to this region, Rajnagar does not have a single industry (small or large scale) till date and is regarded as one of the most undeveloped regions of coastal Odisha. Major part of the region is hard to access with vehicle and the area is still to witness any kind of rail network. The region has witnessed some kind of development of the tourism sector with the establishment of Vitarkanika crocodile sanctuary only very recently. In stark contrast to other parts of the district, the rural areas or villages are sparsely distributed and many still do not have the facility of electricity supply. The livelihood of population depends on agriculture and to some extent on fisheries for those living close to the coast [24]. The area has an extent of approximately $86.65^{\circ} \mathrm{E}$ to
$87.10^{0} \mathrm{E}$ longitude and $20.50^{\circ} \mathrm{N}$ to $20.79^{\circ} \mathrm{N}$ latitude. The tidal influence of the Bay of Bengal on the east coast of the study area has facilitated the profound growth of mangrove forests along the coast line which holds the key to the sustainment of crocodile and bird sanctuaries.

\section{GEOLOGY}

The concentration of dissolved material in groundwater is normally greater than that of the surface waters due to their greater exposure to geologic strata [1]. The type and concentration of the salts do depend on the mineralogical characteristics of the aquifer and their solubility as well. A detailed analysis of the geologic setting of the study area was done based on the geological map which has been established by the Geological Survey of India for the state of Odisha (Fig. 2). A detailed geological investigation of the Rajnagar block from the Geological Survey of India map illustrates the presence of two types of geologic formations covering the region including Burahbalang formation and the Bankigarh formation (Fig. 2). Both types of formations

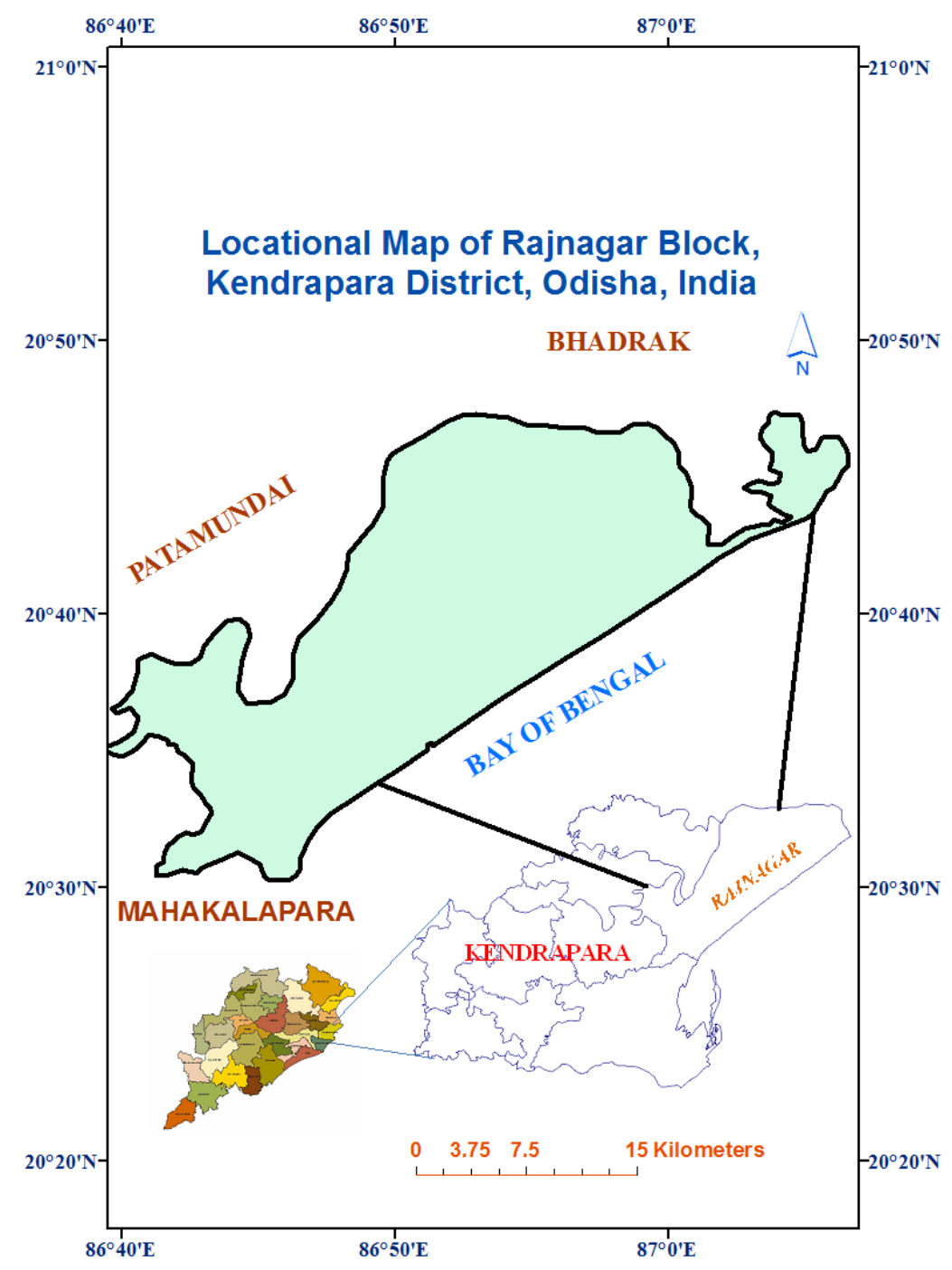


Fig -1: Physiographic setting of the study area

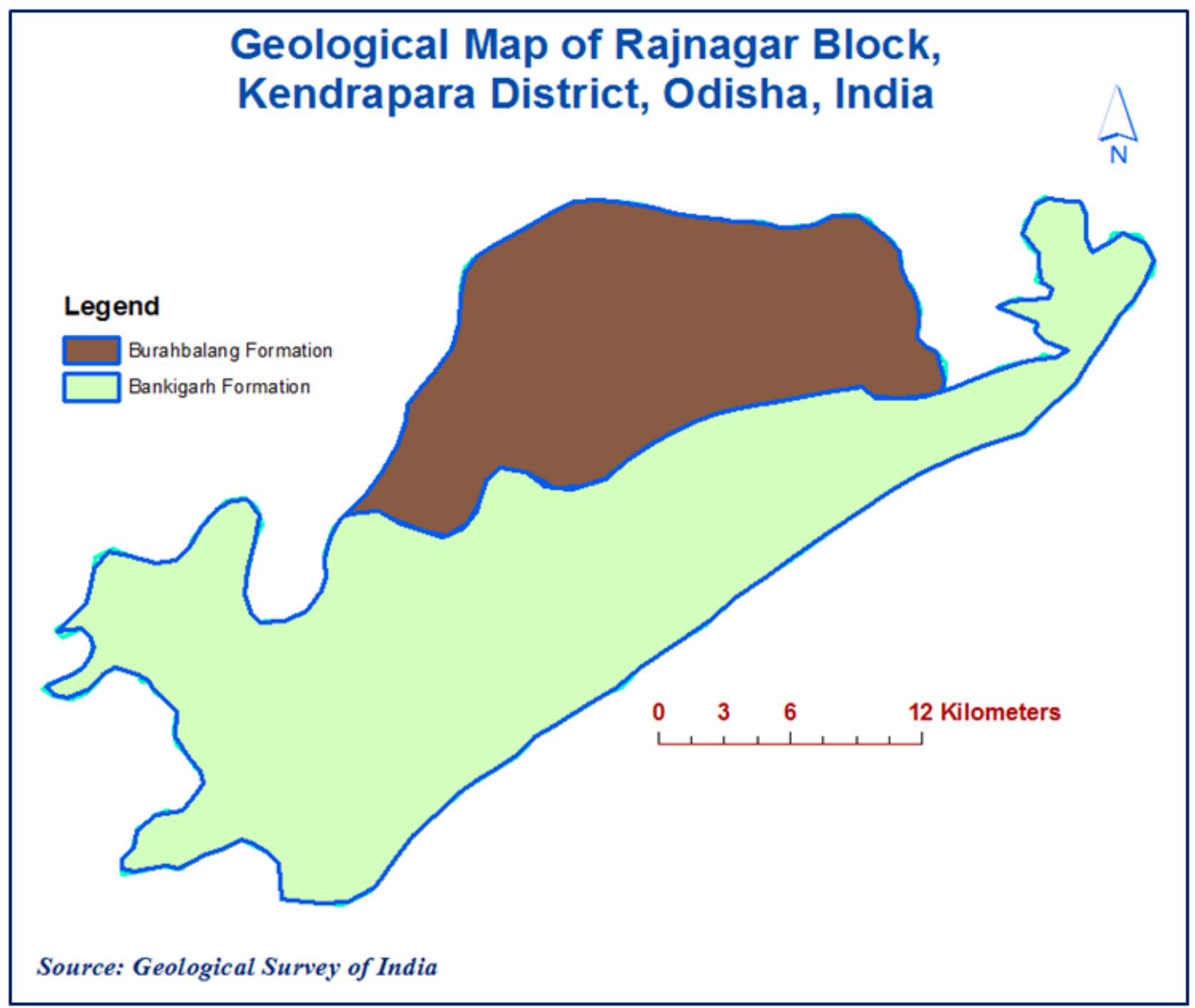

Fig - 2: Geology of the study area

belong to the deltaic and marine sedimentary deposits. The two formations practically divide the region into two halves in a north south direction. The Bankigarh formation occupies a considerable part of the southern and northeastern part of the study area and consists of old sand dunes, marine clay, fluvial silt or clay and deltaic deposits. The northern region of the study area points to the presence of a distinct belt of Burahbalang formation where the stratigraphy consists of sand silt in alternating flood plain layers, recent sand dunes and marine deposits.

\section{TOPOGRAPHY}

The topographical elements of the study area are derived from the geospatial analysis of SRTM DEM in ArcGIS 10 [16]. The chief elements essential for a morphometric analysis are slope, aspect and curvature of the terrain and these were established to obtain a synoptic view of the region. The calculated slope of the terrain from elevation values displays the gradient or inclination between two points for the water movement. A peek at the elevation map points towards the region being very gently sloped low lying area which is generally the characteristic of coastal plains worldwide (Fig. 3). Two predominant minimum and maximum slopes of $0^{\circ}$ and $90^{\circ}$ respectively are observed from the slope map of the terrain (Fig. 3). The zero values are represented by the stream channels and water bodies whereas the near vertical slopes indicate flat lying areas of the terrain and the forested areas. The aspect values of Rajnagar displays a similar view as that of the slope map having a dominant eastwardly facing topography which is clearly depictable from the physiographic setting of the study area (Fig. 3).

The morphometric element of curvature indicates the second derivative of the slope of the topography which can be interpreted in terms of acceleration or deceleration of the flow of water along the slope. This element of the terrain also gives a similar result as that of the slope and aspect of the terrain. The curvature map displays a very homogenous or isotropic nature of the region (Fig. 3). In a nut shell, the above three morphometric elements of terrain indicates a 
very gently sloping eastwardly facing topography merging

with the Bay of Bengal in the east.

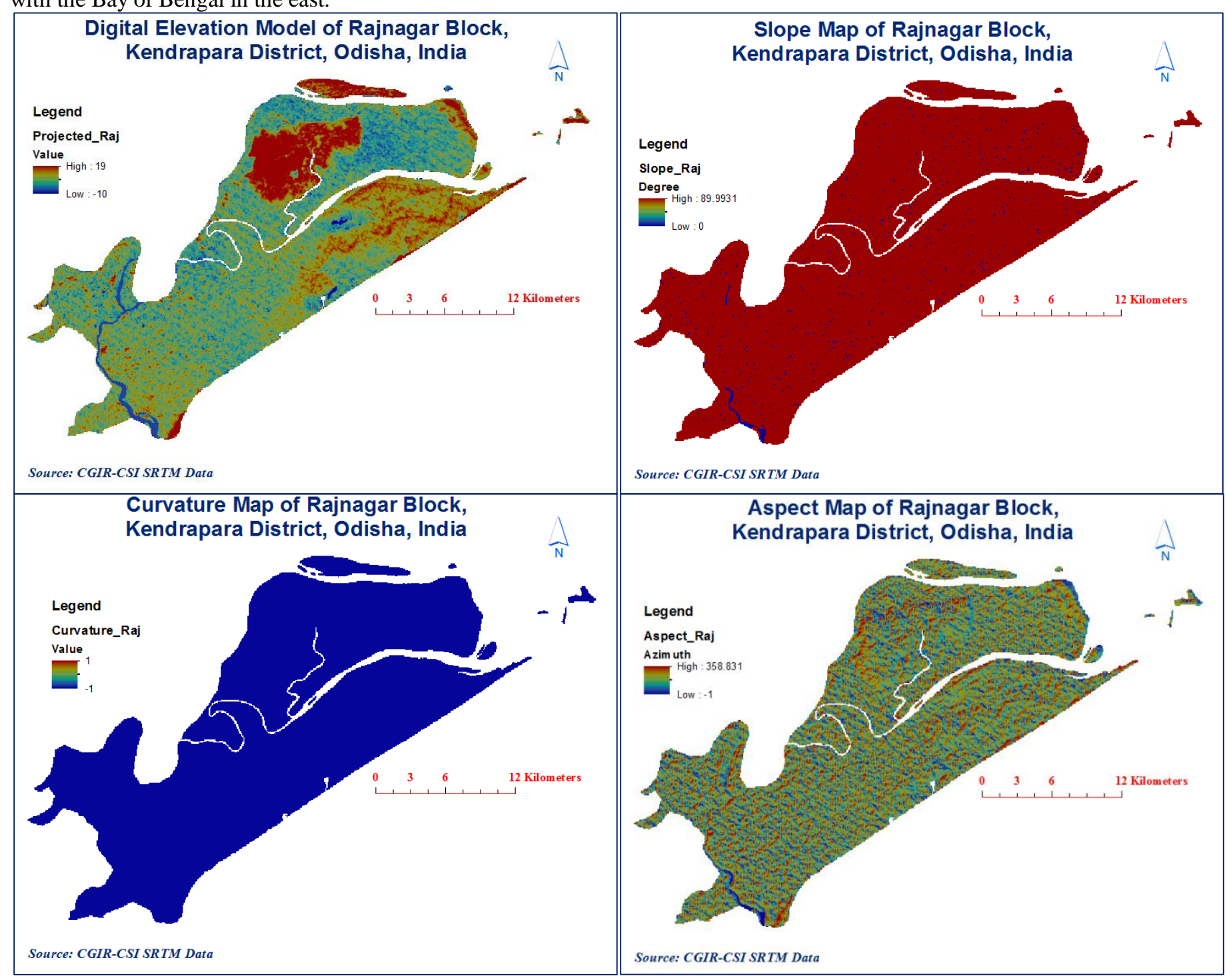

Fig - 3: Topographic elements of the study area

\section{MATERIALS AND METHODOLOGY}

Groundwater sample collection for the present study has been done in accordance with the standard methods of 1060 , APHA, 1995 from the various places within the study site[9, $10,11,12,13,14,15,17]$. The groundwater samples were collected keeping in mind the cultural set up, hydrology, geology and topography of the terrain in mind so that, they are representative of the aquifer system of concern $[5,6]$. This was followed so as to find out any specific spatial pattern that exists within the study site. A total of 53 ground water samples were collected in June 2013 before the onset of the monsoon (Fig. 4).

The samples were collected in $300 \mathrm{ml}$ low density polyethylene narrow mouth bottle (conforming to USP Class IV) with leak-proof and air tight lid. Before collecting the samples from the required source, certain amount of water was first pumped out (in spite of the concern tube well being an active public tube well) so that fresh drawn down groundwater is collected (not stored water). Collector's hand was properly washed and the sampling bottles were rinsed with same water for few seconds before collecting the water samples. During the collection of water samples the location of the site was identified by GPS device (GARMIN NUVI 250) $[5,6]$. The labelling of the samples was done in such a manner so that it clearly demonstrates the system (e.g. well or tube-well or bore well), sampling site and sample number. The date and time of the sampling was also noted down during the collection of the samples. As soon as the samples were collected, they were labelled and capped and packaged in foam box that was used exclusively for this purpose. 


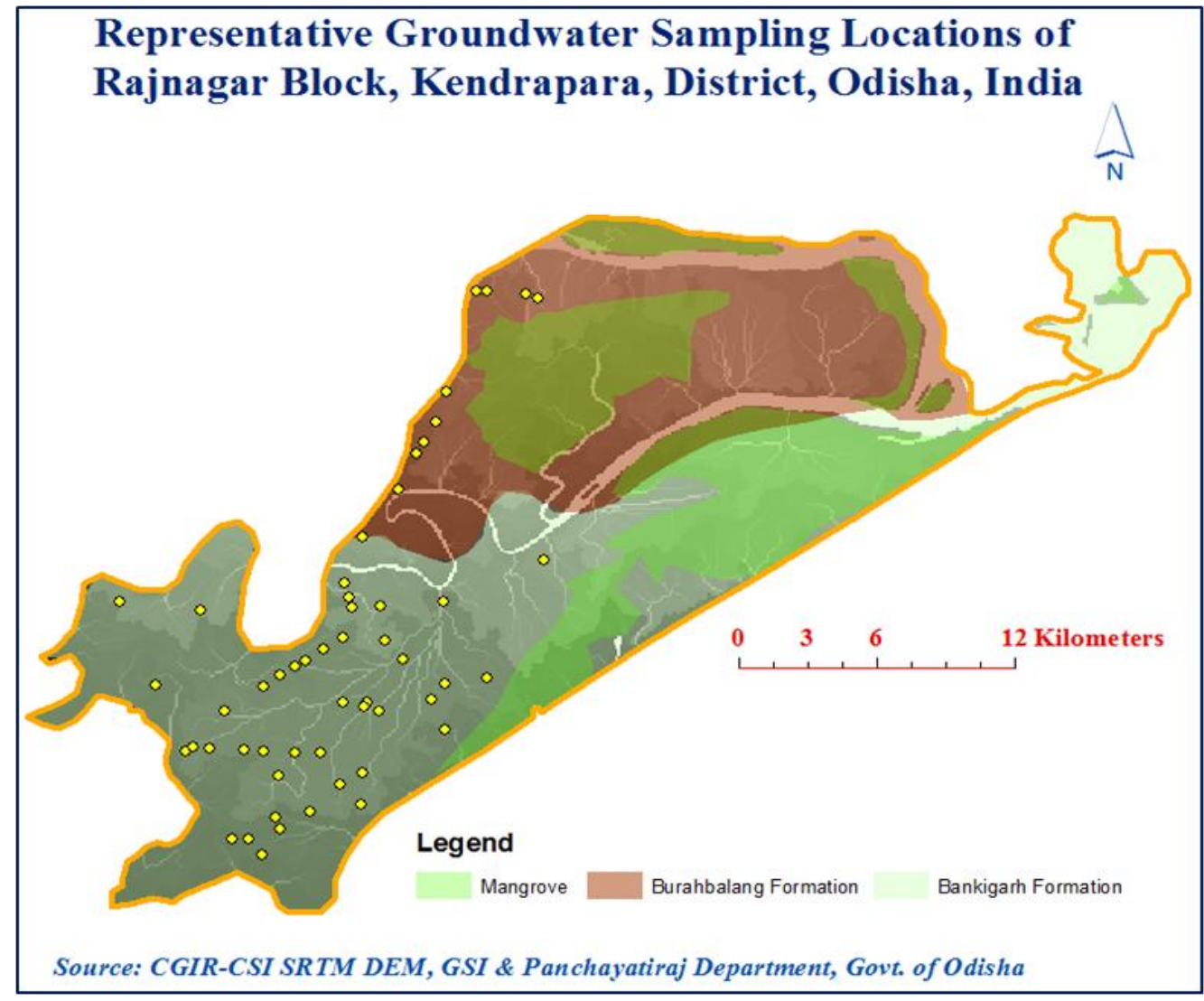

Fig - 4: Groundwater sampling locations of study area

Physical parameters like pH, Electrical Conductance (EC) were measured on the spot by Systronics Water analyzer 371 and total dissolved solid (TDS) concentration was calculated by multiplying a factor of 0.64 to the corresponding EC values. Total hardness (TH) of the groundwater samples were estimated by titration with the chelating agent ethylenediaminetetraacetic acid (EDTA). EDTA forms stable complex ions with divalent cation as below illustrated explanation for calcium:

$\mathrm{Ca}^{2+}+$ EDTA $=$ Ca.EDTA

Thus every molecule of EDTA will form complex with one divalent metal cation which in turn points to one mole of EDTA consumed being equal to 1 mole of $\mathrm{CaCO}_{3}$ equivalence of $\mathrm{TH}$. The titration procedure uses ammonia buffer and Erochrom Black Tea (EBT) as reagent solutions. The calculated TH concentrations of the collected groundwater samples are given in Table 1.

\section{RESULTS AND DISCUSSION}

Groundwater is considered to be soft when it has a TH value less than $75 \mathrm{mg} / \mathrm{l}$, moderately hard when the value ranges between $75 \mathrm{mg} / \mathrm{l}$ to $150 \mathrm{mg} / \mathrm{l}$, hard when the value is $150 \mathrm{mg} / \mathrm{l}$ to $300 \mathrm{mg} / \mathrm{l}$ and very hard when the hardness concentration is beyond $300 \mathrm{mg} / \mathrm{l}[3,4]$. The hardness of groundwater samples of Rajnagar block have a very smaller range from $110 \mathrm{mg} / 1$ to $225 \mathrm{mg} / 1$ out of which, 22 samples $(41.5 \%)$ are moderately hard waters and the rest $31(58.5 \%)$ belong to the hard water category.
To determine the spatial distribution of the different groundwater types, the hardness concentration of the samples were analyzed in a GIS environment (Fig. 2). Arc GIS 10 was used to spatially interpolate the $\mathrm{TH}$ concentrations of collected groundwater samples. Digital Elevation Model (DEMs) was created for each water type (where the concentration is displayed as elevation) to know the lateral variation of the groundwater hardness (Fig. 5). As displayed from the DEM, there is a distinct belt of moderately hard groundwater in the central-northwestern part of the Rajnagar block.

As found out from the hydrochemical analysis as well as that displayed in the DEM the study area is practically devoid of soft groundwater horizons and the water type mainly falls within the hard water category. This lateral occurrence assumes greater significance in future as the area is still to witness any significant industrialization and hence the type of industry that can be thought of to be set up. Analysis of the correlation of TH values with that of $\mathrm{pH}$ and EC values displayed no significant interrelationship (Table 2).

\section{CONCLUSION}

The present research looks into the spatial distribution of hardness of groundwater in the coastal Kendrapara district. Analysis of the 53 representative groundwater samples from the area displays the wide spread occurrence of moderately had to hard groundwater types throughout the study area. 


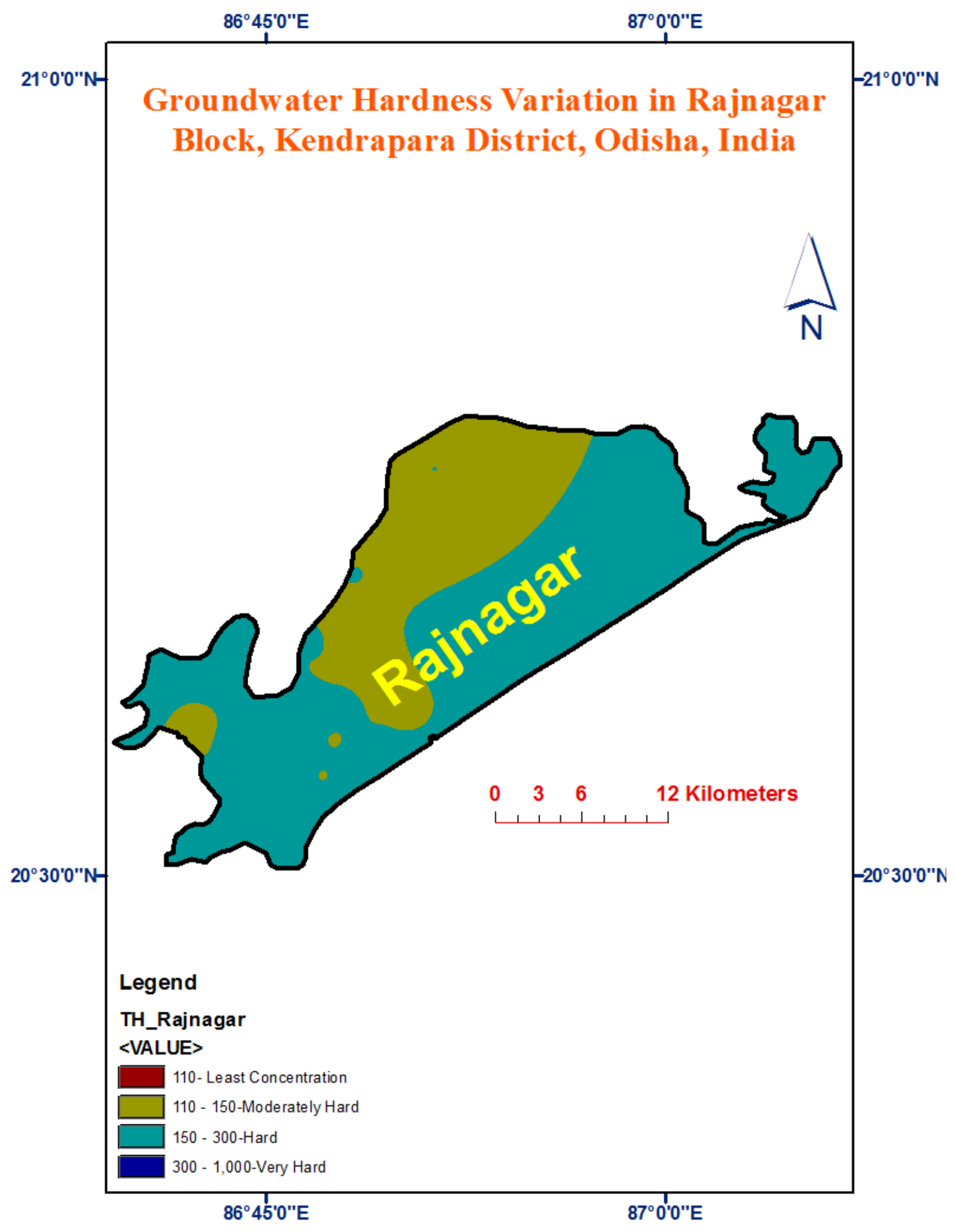

Fig - 5: Spatial variation of groundwater type in the study area 
Table -1: Total Hardness of Groundwater Samples of Rajnagar Block, Odisha, India

\begin{tabular}{|c|c|c|c|c|}
\hline \multicolumn{5}{|c|}{ Rajnagar Block } \\
\hline Sample No. & PH & $\mathrm{EC}(\mu \mathrm{s} / \mathrm{cm})$ & TDS(mg/l) & TH(mg/l) \\
\hline RPT - 1 & 6.87 & 1210 & 774.40 & 220 \\
\hline RPT - 2 & 6.81 & 998 & 638.72 & 160 \\
\hline RPT - 3 & 6.86 & 1080 & 691.20 & 170 \\
\hline RPT - 4 & 6.87 & 1050 & 672.00 & 160 \\
\hline RPT - 5 & 6.92 & 1020 & 652.80 & 150 \\
\hline RPT - 6 & 6.85 & 1080 & 691.20 & 170 \\
\hline RPT - 7 & 6.96 & 1160 & 742.40 & 180 \\
\hline RPT - 8 & 7.25 & 1580 & 1011.20 & 180 \\
\hline RPT - 9 & 7.06 & 1500 & 960.00 & 175 \\
\hline RPT - 10 & 7.08 & 2060 & 1318.40 & 225 \\
\hline RPT - 11 & 6.99 & 1210 & 774.40 & 170 \\
\hline RPT - 12 & 6.98 & 1280 & 819.20 & 190 \\
\hline RPT - 13 & 6.92 & 1100 & 704.00 & 190 \\
\hline RPT - 14 & 6.96 & 1120 & 716.80 & 190 \\
\hline RPT - 15 & 6.81 & 1200 & 768.00 & 165 \\
\hline RPT - 16 & 6.78 & 1000 & 640.00 & 160 \\
\hline RPT - 17 & 6.74 & 1620 & 1036.80 & 205 \\
\hline RPT - 18 & 6.92 & 1060 & 678.40 & 165 \\
\hline RPT - 19 & 6.87 & 1020 & 652.80 & 155 \\
\hline RPT - 20 & 6.9 & 1340 & 857.60 & 160 \\
\hline RPT - 21 & 6.92 & 1130 & 723.20 & 140 \\
\hline RPT - 22 & 6.9 & 1210 & 774.40 & 165 \\
\hline RPT - 23 & 6.66 & 996 & 637.44 & 150 \\
\hline RPT - 24 & 6.86 & 959 & 613.76 & 185 \\
\hline RPT - 25 & 6.97 & 979 & 626.56 & 110 \\
\hline RPT - 26 & 6.91 & 1030 & 659.20 & 180 \\
\hline RPT - 27 & 6.99 & 1040 & 665.60 & 150 \\
\hline RPT - 28 & 6.76 & 1020 & 652.80 & 150 \\
\hline RPT - 29 & 6.78 & 1020 & 652.80 & 170 \\
\hline RPT - 30 & 6.77 & 961 & 615.04 & 150 \\
\hline RPT - 31 & 6.78 & 938 & 600.32 & 195 \\
\hline RPT - 32 & 6.93 & 1100 & 704.00 & 175 \\
\hline RPT - 33 & 6.99 & 1020 & 652.80 & 140 \\
\hline RPT - 34 & 6.78 & 1050 & 672.00 & 130 \\
\hline RPT - 35 & 6.82 & 1070 & 684.80 & 180 \\
\hline RPT - 36 & 6.8 & 1070 & 684.80 & 115 \\
\hline RPT - 37 & 6.81 & 1040 & 665.60 & 135 \\
\hline RPT - 38 & 6.82 & 1140 & 729.60 & 145 \\
\hline RPT - 39 & 6.81 & 1090 & 697.60 & 165 \\
\hline RPT - 40 & 6.99 & 1180 & 755.20 & 145 \\
\hline RPT - 41 & 7.01 & 1150 & 736.00 & 160 \\
\hline RPT - 42 & 6.95 & 1120 & 716.80 & 130 \\
\hline RPT - 43 & 6.79 & 940 & 601.60 & 120 \\
\hline RPT - 44 & 7.43 & 1160 & 742.40 & 110 \\
\hline RPT - 45 & 7.03 & 1170 & 748.80 & 115 \\
\hline RPT - 46 & 7.06 & 1180 & 755.20 & 145 \\
\hline RPT - 47 & 7.15 & 1160 & 742.40 & 115 \\
\hline RPT - 48 & 7.13 & 1140 & 729.60 & 155 \\
\hline RPT - 49 & 7.07 & 1140 & 729.60 & 165 \\
\hline RPT - 50 & 7.02 & 1260 & 806.40 & 145 \\
\hline RPT - 51 & 7.08 & 1150 & 736.00 & 135 \\
\hline RPT - 52 & 7.11 & 1360 & 870.40 & 185 \\
\hline RPT - 53 & 7.38 & 1150 & 736.00 & 145 \\
\hline
\end{tabular}

Table -2: Correlation between Different Hydro-chemical Parameters of Groundwater samples

\begin{tabular}{|ccccc|}
\hline & PH & EC( $\mu \mathrm{s} / \mathrm{cm})$ & TDS $(\mathrm{mg} / \mathrm{l})$ & $\mathrm{TH}(\mathrm{mg} / \mathrm{l})$ \\
PH & 1.00 & & & \\
$\mathrm{EC}(\mu \mathrm{s} / \mathrm{cm})$ & 0.38 & 1.00 & & \\
$\mathrm{TDS}(\mathrm{mg} / \mathrm{l})$ & 0.38 & 1.00 & 1.00 & \\
$\mathrm{TH}(\mathrm{mg} / \mathrm{l})$ & -0.15 & 0.45 & 0.45 & 1.00 \\
\hline
\end{tabular}

The hardness concentration of the subsurface waters also does not display any significant interrelationship with the physical parameters such as $\mathrm{pH}$ and $\mathrm{EC}$. These findings hold greater future scope regarding the type of industry to be chosen for this backward region.

\section{ACKNOWLEDGEMENTS}

The authors sincerely acknowledge the support provided by the department of Geology, Utkal University for providing field and laboratory equipments as well as lab chemicals for carrying out the various field and laboratory analysis related to this research. The authors also sincerely thank Dr. R. N. Hota, Mrs. P. P. Mohapatra, Mr. Satyanath Mohapatra, Mrs. Susmita Sahu and Mr. Prafulla Mohapatra for their kind support and cooperation during various stages of this research.

\section{REFERENCES}

[1] Birdie G.S. and Birdie J.S., (2010), Water Supply and Sanitary Engineering. Eighth Edition. Dhanpat Rai Publishing Company.

[2] Boyd, C. E. (2000), Water quality. Kluwer Academic Publishers

[3] Todd, D.K., (2001), Ground water hydrology, $2^{\text {nd }}$ edition

[4] Garg, S. K. (2009), Water supply engineering. Khanna Publishers

[5] Das P. P. and Sahoo H. K., (2014). Designing Representative Groundwater Sampling of Mahakalapara Block, Kedrapara District, Odisha: A Comprehensive Hydro-geologic Analysis by GIS Approach. International Journal of Latest Technology in Engineering, Management and Applied Sciences, Vol. III, Issue X, pp - 63-68.

[6] Das P. P. and Sahoo H. K., (2014). A Geospatial Evaluation of SRTM DEM for Representative Groundwater Sampling of Rajnagar Block, Odisha, India. International Journal of Emerging Technology and Advanced Engineering, Vol. 4, Issue 11, pp. 95103. Sundaray D., Sahoo T., Biswal S., Das P. P. and sahoo. S. (2014), Spatial Interpolation of Iron Contaminationaround the industrial belts of eastern Odisha. International Journal of Latest Technology in Engineering, Management and Applied Sciences, Vol. III, Issue IX, pp - 49-57.

[7] Kar, D.K., and Sahoo, H.K., (2012), Hydrogeochemical Evaluation and groundwater 
pollution studies around Kalinganagar industrial complex, Jajpur District, Odisha, Environmental Geochemistry, Vol -15, No.1, pp 25-30.

[8] Edzwald J. K. (1999), Water Quality and Treatment: A handbook of Drinking Water. Sixth edition, McGraw-Hill Companies.

[9] U.S. Geological Survey, (1977), National Handbook of Recommended Methods for Water-Data Acquisition. USGS Office of Water Data Coordination, Reston, Virginia.

[10] Wood, W. W., (1976), Guidelines for Collection and Field Analysis of Groundwater Samples for Selected Unstable Constituents. In: U.S. Geological Survey Techniques for Water Resources Investigations, Book 1, Chapter D-2.

[11] Scalf, M. R., J. F. McNabb, W. J. Dunlap, R. L. Cosby, and J. Fryberger., (1981), Manual of Ground-Water Quality Sampling Procedures. National Water Well Association, Worthington, Ohio.

[12] Brass, H. J., M. A. Feige, T. Halloran, J. W. Mellow, D. Munch, and R. F. Thomas., (1977), The National Organic Monitoring Survey: Sampling and Analyses for Purgeable Organic Compounds. In: Drinking Water Quality Enhancement through Source Protection (R.B. Pojasek, cd.), Ann Arbor Science Publishers, Ann Arbor, Michigan.

[13] Tinlin, R. M., ed. 1976. Monitoring Groundwater Quality: Illustrative Examples. EPA 600/4-76-036, USEPA, Environmental Monitoring and Support Laboratory, Office of Research and Development, Las Vegas, Nevada.

[14] Barcelona M. J., Gibb J. P., Helfrich J. A. and Garske E. E., (1985), Practical Guide for Groundwater Sampling Illinois State Water Survey Champaign, Illinois, ISWS Contract Report 374.

[15] Claassen, H. C., (1982), Guidelines and Techniques for Obtaining Water Samples That Accurately Represent the Water Chemistry of an Aquifer. U.S. Geological Survey, Open-File Report 82-1024, Lake, Colorado, 49 pp.

[16] http://srtm.csi.cgiar.org/SELECTION/inputCoord.as $\mathrm{p}$

[17] Gibb, J. P., R. M. Schuller, and R. A. Griffin., (1981), Procedures for the Collection of Representative Water Quality Data from Monitoring Wells. Cooperative Groundwater Report 7, Illinois state Water Survey and Illinois State Geological Survey, Champaign, Illinois.. 